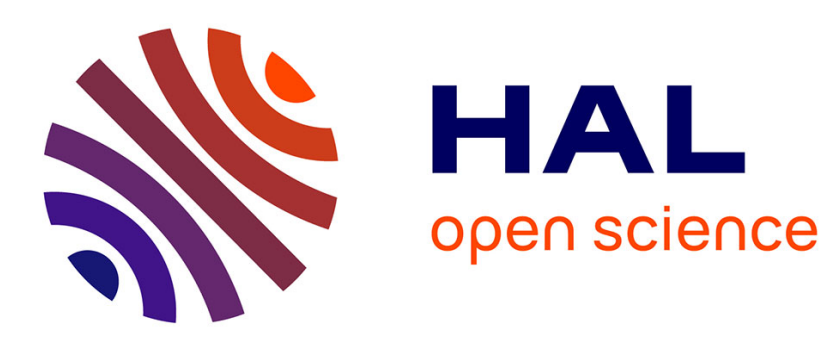

\title{
RIVERINE MIGRATION OF YOUNG EELS ANGUILLA ANGUILLA (L.)
}

Christopher Moriarty

\section{To cite this version:}

Christopher Moriarty. RIVERINE MIGRATION OF YOUNG EELS ANGUILLA ANGUILLA (L.). Vie et Milieu / Life \& Environment, 1986, pp.266. hal-03024135

\section{HAL Id: hal-03024135 \\ https://hal.sorbonne-universite.fr/hal-03024135}

Submitted on 25 Nov 2020

HAL is a multi-disciplinary open access archive for the deposit and dissemination of scientific research documents, whether they are published or not. The documents may come from teaching and research institutions in France or abroad, or from public or private research centers.
L'archive ouverte pluridisciplinaire HAL, est destinée au dépôt et à la diffusion de documents scientifiques de niveau recherche, publiés ou non, émanant des établissements d'enseignement et de recherche français ou étrangers, des laboratoires publics ou privés. 


\section{RIVERINE MIGRATION OF YOUNG EELS ANGUILLA ANGUILLA (L.)}

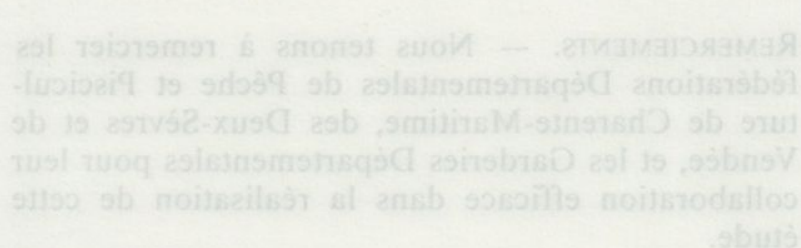

Eels of length $6 \mathrm{~cm}$ to $50 \mathrm{~cm}$ trapped in the course of upstream migration in the River Shannon have been sampled during ten seasons from 1973 to 1983 . Migration normally begins at the end of May at water temperatures of $13{ }^{\circ}$ or $14^{\circ} \mathrm{C}$ but the extreme dates range from 17 May to 24 June. In five out of seven years migration ended between 10 and 19 September, in the other two on 29 July and 6 October. Positive correlations were observed between date of first migration and temperature between 15 and 21 May. No connection between temperature and date of end of migration was apparent. Length measurements of 5008 eels showed that large individuals $(>15 \mathrm{~cm})$ migrated throughout the season but that the majority of

\section{Christopher MORIARTY}

Department of Fisheries and Forestry Fisheries Research Centre Abbotstown, Castleknock Dublin 15, Ireland

smaller eels $(<10 \mathrm{~cm})$ had a shorter migration period, from mid June to mid August. Ages of 158 specimens were determined. The maximum age was $10+$, the majority ranged from $1+$ to $3+$. Elvers of $0+$ were scarce or absent early in the season and were never plentiful. Number of eels caught ranged from 131000 to 417000 per year. It was concluded that a number of factors influenced migration of the eels, the time of year perhaps the strongest, with water temperature in May being secondary. Migration of the greatest numbers occurred in the year following the greatest immigration of elvers to the river. This suggests that migration may be influenced by population pressure in the lower reaches of the river. 